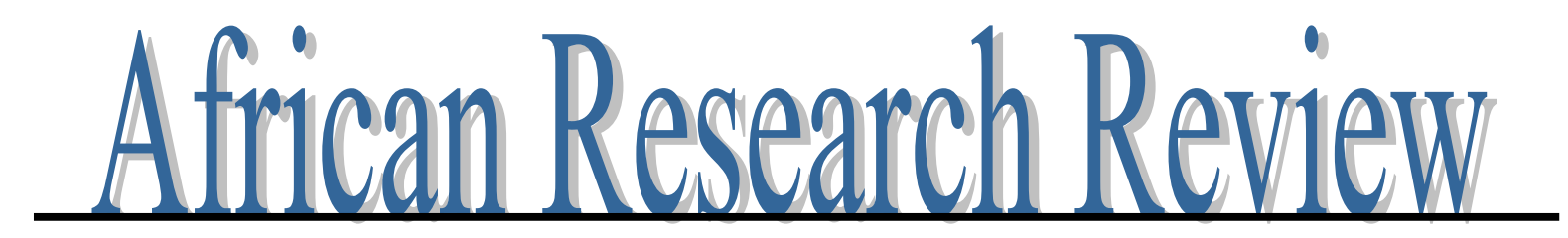

An International Multidisciplinary Journal, Ethiopia

Vol. 8(3), Serial No. 34, July, 2014:116-122

ISSN 1994-9057 (Print) ISSN 2070--0083 (Online)

DOI: http://dx.doi.org/10.4314/afrrev.v8i3.10

\title{
Impact of Solid Waste on Physico-Chemical Properties of Ferrealsol in Owerri, Nigeria
}

\author{
Okeke, P. N. \\ Department of Environmental Technology \\ Federal University of Technology, P. M. B. 1526 Owerri \\ Imo State, Nigeria \\ Email: nduokeke100@yahoo.com
}

\begin{abstract}
The effects of municipal solid waste on selected physico-chemical properties of ferralsol in Owerri were examined. Soil samples were collected at different depths of $0-30 \mathrm{~cm}$ and $30-60 \mathrm{~cm}$ from polluted and unpolluted (control) areas. Selected physical and chemical properties such as bulk density, $\mathrm{pH}$, total nitrogen, organic carbon, exchangeable bases, available phosphorus, and heavy metals ( $\mathrm{Pb}, \mathrm{Cr}$, and $\mathrm{Fe}$ ) were determined using standard methods. The findings show that the bulk density (1.15$1.5 \mathrm{~g} / \mathrm{cm})$ and $\mathrm{pH}(4.6-5.4)$ were lower in the polluted area than in the control. Other parameters such as organic matter (2.06-5.21\%), organic carbon (1.90-3.20\%), total nitrogen (0.24-0.61\%), available phosphorus (4.2-5.1ppm), and the exchangeable bases were higher in the polluted area than the control. The results further indicate that the heavy metals with values above the control and permissible limits posed the greatest danger to animals and humans. There is a need therefore for proper management of municipal solid waste in Owerri.
\end{abstract}

\section{Introduction}

Solid wastes in forms of municipal solid waste (MSW), Biological solid waste (BSW), and Industrial solid waste (ISW) are most often disposed on land as tips or spoils heaps or as land infill to quarries and mine shafts or as dumps consisting of a wide range of materials (De, 2003). Waste disposal on land is a common method practiced almost by all the cities around the globe (Jeyapriya and Saseetharam, 2010). 
The management of solid waste in Owerri Municipal Council is however not an exception to this procedure.

The Council sanitation agency collect, transport and dump solid wastes at a permanent site at the out shirt of the town. In the dry season, when the waste is being burnt, it releases particulate matter such as ash, smoke, dust an fumes that contain pollutant gases (oxides of nitrogen, sulphur and carbon) (Bhatia, 2009). During the rains water that infiltrate through the solid wastes leach the constituents from the decomposed mass and while percolating cause the subsurface to be contaminated by organic and inorganic solutes (Teyariya and Sasectharam, 2010). Some researchers (Shelton, 1991; wild 1993; Erickson, 1999: Brady and Weil, 1999; and cooper and Leslie, (2002) had also reported on the impact of solid waste on soil properties. However, this study attempts to assess the effects of solid waste on selected physicochemical properties of ferrealsol in Owerri, Nigeria. This study becomes more significant because crops growing in the polluted dumpsite were being consumed by domestic animals, and these domestic animals are consumed by humans. Thus any toxic element in the waste that is absorbed by the plants can move up the trophic level to man.

\section{Methodology}

\section{Soil sampling and preparation}

Soil samples were collected from polluted (PAI, PA2, and PA3) area and unpolluted control area (CA) at depths of $0-30 \mathrm{~cm}$ (topsoil) and $30-60 \mathrm{~cm}$ (subsoil). Three composite samples were each collected from the topsoil and subsoil of the polluted area while one each was sampled from similar depths in the control area. The samples for the determination of bulk density was collected with $100 \mathrm{~cm}$ metal rings, packed in the sample box before taken to the laboratory. Soil auger was used for sampling soils for the analysis of other parameters. In the laboratory, all the samples except those for the bulk density were air-dried and sieved with a $2 \mathrm{~mm}$ sieve before the analysis.

\section{Laboratory analyses}

The soil particle size analysis was determined by hydrometer method (Bouyoucos, 1962). Bulk density was determined by core method (Blake, 1965). The soil $\mathrm{pH}$ was measured using a $\mathrm{pH}$ meter in 1:2.5 soil to water ratio. Percentage organic matter was estimated by procedure described by walkley and Black (1934). The exchangeable bases (Ca, Mg, K and Na) were determined by procedure outlined by Jackson (1956). The method described by Bray and Kurtz (1945) was used in determining available phosphorus. Total nitrogen was determined by modified micro-kjeldahl distillation procedure (Bremner, 1965). Atomic Absorption Spectrophotometer (AAS) was used in determining the heavy metals $(\mathrm{Pb}, \mathrm{Cr}$, and $\mathrm{Fe})$. Descriptive statistic was adopted in analyzing the results. 


\section{Results and discussion}

Table 1 shows the physico-chemical properties of the soil samples from both the polluted and control areas. Presented in table 2 are the range, mean, standard deviation, and control values for the parameters. The topsoil and subsoil had mean bulk density of $1.30 \mathrm{mg} / \mathrm{cm}^{3}$ and $1.44 \mathrm{~g} / \mathrm{cm}$ respectively for the polluted area, while the control values were 1.45 and $1.52 \mathrm{~g} / \mathrm{cm} 3$ for the topsoil and subsoil in that order. There was a general increase of bulk density with depth. This can be attributed to the migration of clay and other minerals from the topsoil to the subsoil following rainfall. The high organic matter content found in the topsoil increased soil porosity thus allowing more water to infiltrate and percolate into the subsoil. The percolating water transports clay particle to the subsoil where they cause low porosity, increased soil mass and low hydraulic conductivity.

Low water infiltration rate results to high overland flow which can cause soil erosion and nutrient loss. The lower mean bulk density values obtained in the polluted area relative to the control was probably due to more organic matter content from dumped organic waste. Organic matter increases soil volume and decreases soil mass. Shelton (1991) and Aggclides and Bend (2000) similarly obtained a reduction of bulk density with the additional of MSW and compost.

The average $\mathrm{pH}$ value for the polluted soil was 5.3 (topsoil) and 4.9 (subsoil). The values for the control were 5.7 (topsoil) and 5.3 (subsoil). The lower $\mathrm{pH}$ value obtained in the polluted area could be as a result of the impact of organic matter from the waste dumped in the area. Decomposition of organic matter releases carbon dioxide which reacts with water to form carbonic acid which reduces soil $\mathrm{pH}$.

\section{Table 1: Results of Physical and Chemical Properties of the Soil Samples}

\begin{tabular}{|c|c|c|c|c|c|c|c|c|}
\hline \multirow{2}{*}{ Location } & \multirow[t]{2}{*}{ Depth cm } & \multicolumn{3}{|c|}{ Particle Size Analysis } & \multirow{2}{*}{$\begin{array}{l}\text { Textural } \\
\text { Class }\end{array}$} & \multirow[t]{2}{*}{$\mathrm{BD} \mathrm{g} / \mathrm{cm}^{3}$} & \multicolumn{2}{|c|}{$\mathrm{pH}(1: 2)$} \\
\hline & & Sand & Silt & Clay & & & $\mathrm{H}_{2} \mathrm{O}$ & $\mathrm{kcl}$ \\
\hline \multirow[t]{2}{*}{ PA1 } & $0-30$ & 76.42 & 9.51 & 14.07 & Sandy loam & 1.3 & 5.2 & 4.3 \\
\hline & $30-60$ & 70.13 & 7.41 & 22.46 & $\begin{array}{l}\text { Sandy Clay } \\
\text { loam }\end{array}$ & 1.51 & 4.6 & 3.9 \\
\hline \multirow[t]{2}{*}{ PA2 } & $0-30$ & 81.22 & 7.85 & 10.93 & Loamy sand & 1.25 & 5.4 & 4.4 \\
\hline & $30-60$ & 73.06 & 8.16 & 18.78 & Sandy sand & 1.40 & 5.1 & 4.1 \\
\hline \multirow[t]{2}{*}{ PA3 } & $0-30$ & 82.21 & 6.29 & 11.5 & Loamy sand & 1.34 & 5.3 & 4.8 \\
\hline & $30-60$ & 74.52 & 8.43 & 17.05 & Loamy sand & 1.41 & 5.0 & 4.5 \\
\hline \multirow[t]{2}{*}{$\mathrm{CA}$} & $0-30$ & 80.01 & 7.02 & 12.97 & Sandy loam & 1.45 & 5.7 & 5.1 \\
\hline & $30-60$ & 74.14 & 4.27 & 21.59 & $\begin{array}{l}\text { Sandy clay } \\
\text { loam }\end{array}$ & 1.52 & 5.3 & 4.9 \\
\hline
\end{tabular}




\begin{tabular}{|c|c|c|c|c|c|c|c|c|c|c|c|}
\hline Location & $\begin{array}{l}\mathrm{OM} \\
(\%)\end{array}$ & $\begin{array}{l}\mathrm{OC} \\
(\%)\end{array}$ & $\begin{array}{l}\mathrm{N} \\
(\%)\end{array}$ & $\begin{array}{l}\mathrm{P} \\
(\mathrm{ppm})\end{array}$ & $\begin{array}{l}\text { Ca Meq/ } \\
100 \mathrm{~g}\end{array}$ & $\begin{array}{l}\text { Mg Meq } \\
100 \mathrm{~g}\end{array}$ & $\begin{array}{l}\text { K } \\
\text { Meq/ } \\
100 g\end{array}$ & $\begin{array}{l}\mathrm{Na} \\
\mathrm{Meq} / 100 \\
\mathrm{~g}\end{array}$ & $\begin{array}{l}\mathrm{Pb} \\
(\mathrm{ppm})\end{array}$ & $\begin{array}{l}\mathrm{Cr} \\
(\mathrm{ppm})\end{array}$ & $\begin{array}{l}\mathrm{Fe} \\
(\mathrm{ppm})\end{array}$ \\
\hline \multirow[t]{2}{*}{ PA1 } & 5.21 & 3.03 & 0.54 & 5.1 & 1.61 & 1.14 & 0.36 & 0.21 & 0.21 & 0.03 & 37.12 \\
\hline & 3.04 & 2.48 & 0.42 & 3.0 & 1.01 & 0.37 & 0.41 & 0.33 & 0.13 & 0.01 & 18.41 \\
\hline \multirow[t]{2}{*}{ PA2 } & 4.65 & 3.20 & 0.61 & 4.3 & 1.02 & 0.82 & 0.6 & 0.47 & 0.24 & 0.10 & 38.21 \\
\hline & 2.41 & 1.90 & 0.31 & 2.4 & 0.52 & 0.74 & 0.51 & 0.32 & 0.16 & ND & 17.84 \\
\hline \multirow[t]{2}{*}{ PA3 } & 4.21 & 3.02 & 0.32 & 4.8 & 0.64 & 1.01 & 0.31 & 0.51 & 0.18 & 0.02 & 24.23 \\
\hline & 2.06 & 1.21 & 0.24 & 2.1 & 0.60 & 0.4 & 0.40 & 0.26 & 0.06 & ND & 13.06 \\
\hline \multirow[t]{2}{*}{$\mathrm{CA}$} & 2.24 & 1.14 & 0.22 & 3.1 & 0.41 & 0.21 & 0.21 & 0.14 & ND & ND & 5.80 \\
\hline & 1.03 & 0.44 & 0.13 & 1.7 & 0.30 & 0.2 & 0.30 & 0.21 & ND & ND & 4.11 \\
\hline
\end{tabular}

Table 2: Descriptive Statistics (Minimum, Maximum, Mean and SD) of the Parameter Values

\begin{tabular}{llllcll}
\hline Parameter & Depth & Min & Max & Mean & SD & Control (CA) \\
$\mathrm{BDg} / \mathrm{cm}^{3}$ & $0-30 \mathrm{~cm}$ & 1.25 & 1.34 & 1.29 & 0.045 & 1.45 \\
& $30-60 \mathrm{~cm}$ & 1.40 & 1.51 & 1.44 & 0.061 & 1.52 \\
$\mathrm{pH}(\mathrm{IN} \mathrm{H} 20)$ & $0-30 \mathrm{~cm}$ & 5.20 & 5.40 & 5.3 & 0.1 & 5.7 \\
& $30-60 \mathrm{~cm}$ & 4.60 & 5.10 & 4.9 & 0.265 & 5.3 \\
$\mathrm{OM}(\%)$ & $0-30 \mathrm{~cm}$ & 4.21 & 5.21 & 4.49 & 0.501 & 2.24 \\
& $30-60 \mathrm{~cm}$ & 2.06 & 3.04 & 2.5 & 0.497 & 1.03 \\
$\mathrm{OC}(\%)$ & $0-30 \mathrm{~cm}$ & 3.02 & 3.20 & 3.08 & 0.101 & 1.14 \\
& $30-60 \mathrm{~cm}$ & 1.21 & 2.48 & 1.86 & 0.636 & 0.44 \\
$\mathrm{~N}(\%)$ & $0-30 \mathrm{~cm}$ & 0.32 & 0.61 & 0.49 & 0.151 & 0.22 \\
& $30-60 \mathrm{~cm}$ & 0.24 & 0.42 & 0.32 & 0.091 & 0.13 \\
$\mathrm{P}(\mathrm{ppm})$ & $0-30 \mathrm{~cm}$ & 4.3 & 5.1 & 4.73 & 0.404 & 3.1 \\
& $30-60 \mathrm{~cm}$ & 2.1 & 3.0 & 2.5 & 0.458 & 1.7 \\
$\mathrm{Ca}(\mathrm{Meq} / 100 \mathrm{~g})$ & $0-30 \mathrm{~cm}$ & 0.64 & 1.61 & 1.09 & 0.489 & 0.41 \\
& $30-60 \mathrm{~cm}$ & 0.52 & 1.01 & 0.71 & 0.263 & 0.32 \\
$\mathrm{Mg}(\mathrm{Meq} / 100 \mathrm{~g})$ & $0-30 \mathrm{~cm}$ & 0.82 & 1.14 & 0.99 & 0.161 & 0.28 \\
& $30-60 \mathrm{~cm}$ & 0.37 & 0.74 & 0.5 & 0.206 & 0.2 \\
$\mathrm{~K}(\mathrm{Meq} / 100 \mathrm{~g})$ & $0-30 \mathrm{~cm}$ & 0.31 & 0.60 & 0.42 & 1.155 & 0.21 \\
& $30-60 \mathrm{~cm}$ & 0.40 & 0.51 & 0.44 & 0.061 & 0.3 \\
$\mathrm{Na}(\mathrm{Meq} / 100 \mathrm{~g})$ & $0-30 \mathrm{~cm}$ & 0.21 & 0.51 & 0.39 & 0.163 & 0.14 \\
& $30-60 \mathrm{~cm}$ & 0.26 & 0.33 & 0.3 & 0.038 & 0.21 \\
$\mathrm{~Pb}(\mathrm{ppm})$ & $0-30 \mathrm{~cm}$ & 0.18 & 0.24 & 0.21 & 0.03 & $\mathrm{ND}$ \\
$\mathrm{Cr}(\mathrm{ppm})$ & $30-60 \mathrm{~cm}$ & 0.06 & 0.16 & 0.12 & 0.051 & $\mathrm{ND}$ \\
$\mathrm{Fe}(\mathrm{ppm})$ & $0-30 \mathrm{~cm}$ & 0.02 & 0.10 & 0.05 & 0.044 & $\mathrm{ND}$ \\
& $30-60 \mathrm{~cm}$ & $\mathrm{ND}$ & 0.01 & 0.01 & 0.01 & $\mathrm{ND}$ \\
& $0-30 \mathrm{~cm}$ & 24.23 & 38.21 & 33.19 & 7.776 & 5.8 \\
& $30-60 \mathrm{~cm}$ & 13.06 & 18.41 & 16.44 & 2.938 & 4.11 \\
\hline
\end{tabular}

The subsoil had lower $\mathrm{pH}$ than the topsoil in both the polluted and control areas. This phenomenon can be attributed to the migration of acidic solution from the topsoil to the subsoil. Low soil pH adversely affects soil microorganisms and also increases the solubility and mobility of heavy metals. 
The organic matter content of the waste dumpsite was high with topsoil value ranging from $4.21-5.21 \%$ and the subsoil value (2.06-3.04\%). The higher percentage value of the topsoil was because organic waste was dumped on the surface soil. Similarly, the higher valued observed in the dumpsite relative to the control was due to the dumped waste. Soil organic matter positively influences the concentrations of parameters such as organic carbon, total nitrogen, and available phosphorus.

Organic carbon decreased with depth in both polluted and unpolluted area (table 1). This was due to the decrease of organic matter with depth. The higher value reported for the polluted area was as a result of the organic component of the municipal waste. High organic carbon can probably lead to high C.N ratio which negatively affects soil fertility. Microbes will first utilize the nitrogen and make little available for plant growth.

The mean percentage value of nitrogen in the polluted area was $0.49 \%$ for the topsoil and $0.32 \%$ for the subsoil. The control had topsoil value $(0.22 \%)$ and subsoil $(0.13 \%)$. The higher value obtained in the polluted area can be attributed to the influence of organic matter and microbial population following the dumping of waste materials. The increased population of the microbes could have led to high rate of mineralization which resulted in more soil nitrogen. The decrease of nitrogen with depth could be linked to the decrease of organic matter with depth.

Available phosphorus had an average value of $4.73 \mathrm{ppm}$ for the topsoil and $2.50 \mathrm{ppm}$ for the subsoil. Similarly, the control values were $3.1 \mathrm{ppm}$ and $1.7 \mathrm{ppm}$ for the topsoil and subsoil respectively. The higher values of phosphorus in the topsoil, and the polluted site can be attributed to the presence of organic matter in the waste. According to Erickson (1999), Aggeliels and Londa (2001), municipal solid waste increases soil organic matter and nutrients.

The exchangeable bases $(\mathrm{Ca}, \mathrm{Mg}, \mathrm{K}$, and $\mathrm{Na}$ ) were generally low in both polluted and control areas (table 2). The low concentrations of these elements can be linked to their low inherent level in the parent rock that transformed into soil. The higher values observed in the polluted area compared to the control is probably due to the input from solid waste material. Microbial breakdown of organic wastes releases these macronutrients into the soil for plants absorption.

Heavy metals $(\mathrm{Pb}, \mathrm{Cr}$, and $\mathrm{Fe})$ were generally high in the polluted area. Mean lead values were $0.45 \mathrm{ppm}$ and $0.25 \mathrm{ppm}$ for the topsoil and subsoil respectively. Chromium had average concentrations of $0.05 \mathrm{ppm}$ for the topsoil and $0.01 \mathrm{ppm}$ for the subsoil. Similarly, iron levels were $33.19 \mathrm{ppm}$ for the surface soil and $16.44 \mathrm{ppm}$ for the subsoil. They were all higher than the control values, and accumulated more in the topsoil than the subsoil. The higher concentrations of these metals on the surface soil to high content of the metals in the municipal wastes that were dumped on the surface soil. Lead affects microorganisms by retarding the heterotrophic breakdown 
of organic matter. In plants, the toxicity is localized in the root system (Arikeru, 2002). Chromates act as irritants to the eye, nose and throat, and chronic exposure may lead to liver and kidney damage (Bondy and Mckee, 1991).

\section{Conclusion}

The findings of this study indicate that solid waste had varying effects on the physical and chemical properties of ferrealsol such as bulk density, total nitrogen, organic carbon, available phosphorus, heavy metals etc. Bulk density and $\mathrm{pH}$ were lower in the polluted area than the control area, while other parameters had a reverse trend. The heavy metal concentrations in the polluted area were also higher than the permissible background levels based on this study. This could pose a great danger to animals and humans. It is therefore pertinent to manage municipal solid waste properly in order to minimize their adverse impact on the soil.

\section{References}

Aggclides C. \& Benda, U (2002). Physical analysis of solid waste material. Blackwell scientific publication, pp 105-106.

Arikeru, M.N. (2002). Heavy metals concentration in selected polluted soils in Oyibo Local Government Area of Rivers State, Nigeria. Unpublished MSc Thesis.

Bhatia, S.C (2009). Environmental pollution and control in chemical process industries. Delhi: Khana publishers.

Blake, G.R (1965). Particle Density. In C.A Blak (ed.) (1965). Methods of soil Analysis part 1; Am Soc. Agron Inc. Madison, Wisconsin, USA.

Bondy, S. \& Mckee, M. (1991). Disruption of the potential across the sunpatosomal plasma membrane and mitochondria by neurotoxic agents. Toxicology letter 58;13-21.

Bouyoucos, G.A (1962). Improved Hydrometer method for making particle size analysis of soils. Agron Jou 54: 464-465.

Brady, N. \& Weil, C. (1999). The nature and properties of soils. 9th Edition. New York: Colllier Macmillan, pp 14-35.

Bray, R.H. \& Kurtz L.T. (1945). Determination of total organic and available forms of phosphorus in soils. Soil science 59:39-45.

Bremner J.M. (1964). Total Nitrogen, methods of soil analysis. America Soci of Agronomy, Madison, Wisconsin 1149-1178. 
Impact of Solid Waste on Physico-Chemical Properties of Ferrealsol in Owerri, Nigeria

Cooper, L. \& Leslie, G. (2002). Soil physical properties and crop production. Fred and sons, pp 340-350.

De, A. K. (2003). Environmental Chemistry. New Delhi: New age international publisher; p. 83.

Erickson, F. (1999). Chemical analysis of solid waste material. First edition, Blackwell scientific publication.

Jackson, M.L. (1958). Soil chemical Analysis. Madison: University of Wisconsin 4758.

Jeyapriya, S. P. \& Seseetharam, M.K. (2010). Effect of municipal solid waste on the characteristic of soil. Pollution Research Paper, Vol. 29. Issue 1, pp 3741.

Shelton, C. (1991). Physical analysis of solid waste material. First edition, Black well scientific publication.

Walkley, A. \& Black, J. A. (1934). Determination of organic carbon in soil. Soil Sc. 37:29-38

Wild, A. (1993). Soil and the environment. New York: John Wiley and sons, pp 9-32. 